\title{
An Overview of High Yield Strength Twinning-Induced Plasticity Steels
}

\author{
Guanghui Yang ${ }^{1}$ and Jin-Kyung Kim ${ }^{2, *}$ \\ 1 Division of Materials Science and Engineering, Hanyang University, Seoul 04763, Korea; \\ gyang@hanyang.ac.kr \\ 2 Department of Materials Science and Chemical Engineering, Hanyang University, Ansan 15588, Korea \\ * Correspondence: jinkyungkim@hanyang.ac.kr; Tel.: +82-31-400-5234
}

Citation: Yang, G.; Kim, J.-K. An Overview of High Yield Strength Twinning-Induced

Plasticity Steels. Metals 2021, 11, 124. https://doi.org/10.3390/met11010124

Received: 17 December 2020

Accepted: 8 January 2021

Published: 10 January 2021

Publisher's Note: MDPI stays neutral with regard to jurisdictional clai$\mathrm{ms}$ in published maps and institutional affiliations.

Copyright: (C) 2021 by the authors. Licensee MDPI, Basel, Switzerland. This article is an open access article distributed under the terms and conditions of the Creative Commons Attribution (CC BY) license (https:// creativecommons.org/licenses/by/ $4.0 /)$.

\begin{abstract}
Twinning-induced plasticity (TWIP) steel is a second-generation advanced high strength steel grade developed for automotive applications. TWIP steels exhibit an excellent combination of strength and ductility, mainly originating from the activation of deformation twinning. However, TWIP steels generally exhibit a relatively low yield strength (YS), which limits their practical applications. Thus, developing high YS TWIP steels without ductility loss is essential to increase their industrial applications. The present work summarizes and discusses the recent progress in improving the YS of TWIP steels, in terms of precipitation strengthening, solid solution strengthening, thermomechanical processing, and novel processes. Novel processes involving sub-boundary strengthening, multi-phase structure, and gradient structure as well as the control of thermomechanical processing (recovery annealing and warm rolling) and precipitation strengthening were found to result in an excellent combination of YS and total elongation.
\end{abstract}

Keywords: TWIP; yield strength; strengthening mechanism; microstructure; thermomechanical processing

\section{Introduction}

High Mn twinning-induced plasticity (TWIP) steel is a second-generation advanced high strength steel grade developed for automotive applications. TWIP steels are characterized by high Mn content ranging from 12 to $30 \mathrm{wt} . \%$, and their main alloying elements besides $\mathrm{Mn}$ include $\mathrm{C}, \mathrm{Al}, \mathrm{Si}$, etc. TWIP steels exhibit an excellent combination of strength and ductility due to the superior strain hardening behavior originating from the activation of deformation twinning [1,2]. The use of TWIP steels can result in a considerable weight reduction of steel components and a reduction of material use [3]. Further, the high energy-absorption capacity of TWIP steels is suitable for applications of crash relevant components in automobiles. However, TWIP steels generally have a relatively low yield strength (YS), which limits their practical applications. For example, the crash performance of TWIP steels can be outperformed by dual phase (DP) steels of the equal ultimate tensile strength (UTS) due to higher YS of the latter [4]. Considerable research has been conducted to tackle the issue of low YS of TWIP steels [5-7].

Classical strengthening mechanisms of metals include grain boundary strengthening [8], precipitation strengthening [9], solid solution strengthening [10], and work hardening [11]. Materials with high strength generally show ductility loss [12]. Various processing methods have been proposed to overcome the strength-ductility trade-off, which can be mainly divided into two directions: (1) Control of the thermomechanical processing [13-15]; (2) Application of novel processing methods to activate multiple strengthening effects $[7,16,17]$.

The present work summarizes representative research works on the improvement of YS in TWIP steels by activation of multiple strengthening mechanisms as illustrated in Figure 1. With regards to novel processing methods, TWIP steels with high YS without 
losing ductility have been reported. For instance, dislocation cell structure [16], multi-phase structure [17], and gradient structure [18] lead to the effective strengthening of TWIP steels without significant loss of ductility.

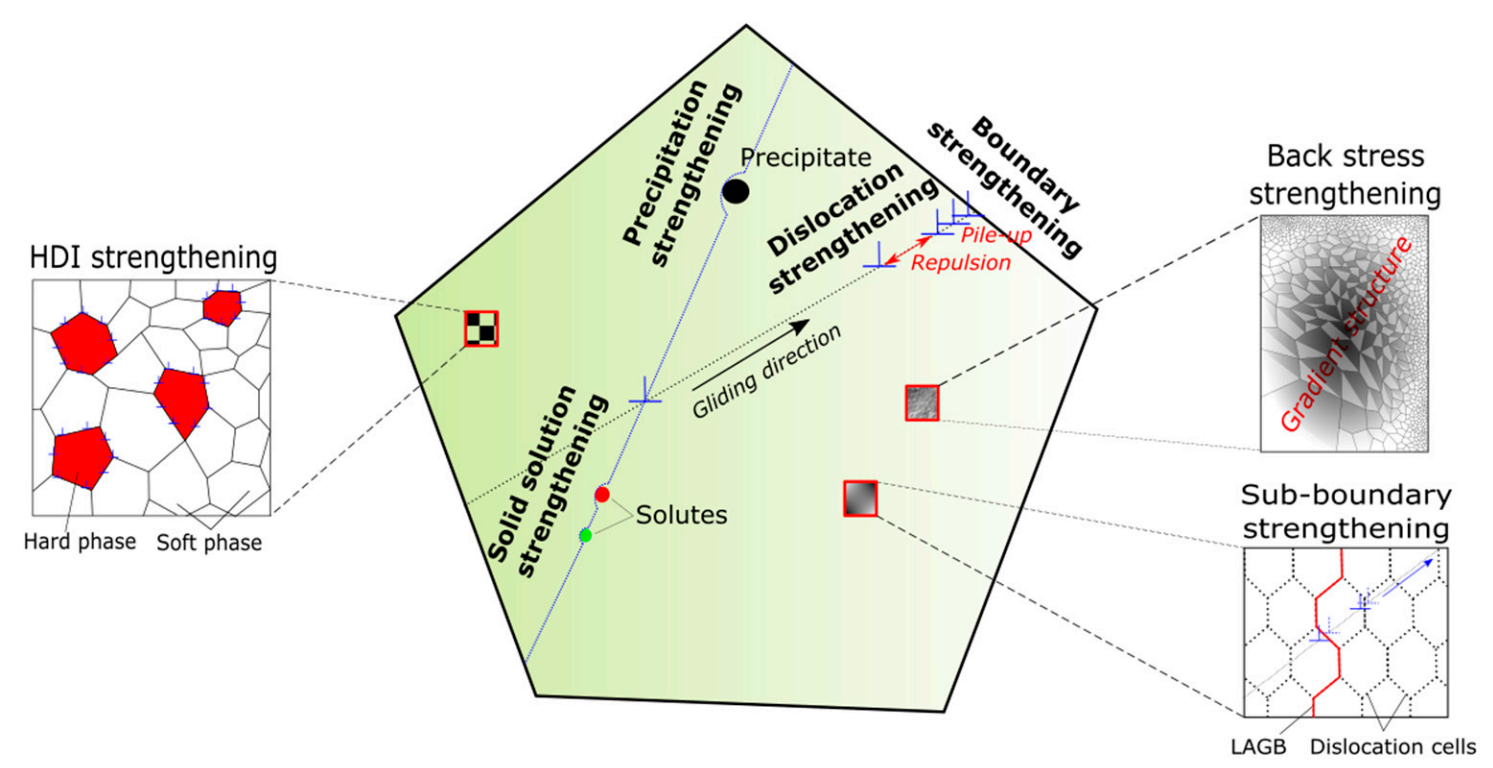

Figure 1. Classical and novel strengthening mechanisms operative in TWIP steels. (LAGB: Low angle grain boundary, HDI: Hetero deformation induced).

\section{Precipitation Strengthening by Nanoscale Precipitates}

Precipitation strengthening has been widely utilized to improve the YS of TWIP steels. The addition of microalloying elements such as Ti [19], V [19-22], Nb [22-25] could significantly enhance the YS of TWIP steels by precipitation of carbides. Nevertheless, the precipitation strengthening mechanisms of TWIP steels by dispersed carbides are not yet fully understood due to the complex nature of the interaction between the carbides and the defects such as dislocations, deformation twins [20,25]. Precipitation strengthening is mainly governed by the interaction of particles with dislocations [9]. According to the Ashby-Orowan relationship, the magnitude of precipitation strengthening $\left(\Delta \sigma_{P}\right)$ in polycrystalline materials is strongly dependent upon volume fraction $(f)$ and size $(D)$ of carbides and described by the following equation [21]:

$$
\Delta \sigma_{P}=0.847 \cdot M \cdot \frac{1.2}{\pi} \cdot G \cdot b \sqrt{\frac{3}{2 \cdot \pi}} \cdot \frac{f^{0.5}}{D} \ln \left(\frac{D}{2 b}\right)
$$

here $M$ is the Taylor factor (3.06 for FCC metals), $G$ and $b$ are the shear modulus ( $~ 74 \mathrm{GPa}$ in TWIP steel [1]) and Burgers vector of perfect dislocations ( $0.25 \mathrm{~nm}$ in TWIP steel [21]), respectively. Figure 2 shows the calculated magnitude of precipitation strengthening using the parameters of $f$ and $D$ reported for TWIP steels [5,19-21]. The analysis clearly shows that nano-sized carbides are highly effective in precipitation strengthening while relatively coarse carbides (large than several tens nanometers) are not very effective in precipitation strengthening. Table 1 summarizes various parameters related to precipitation strengthening of TWIP steels reported from previous works. 


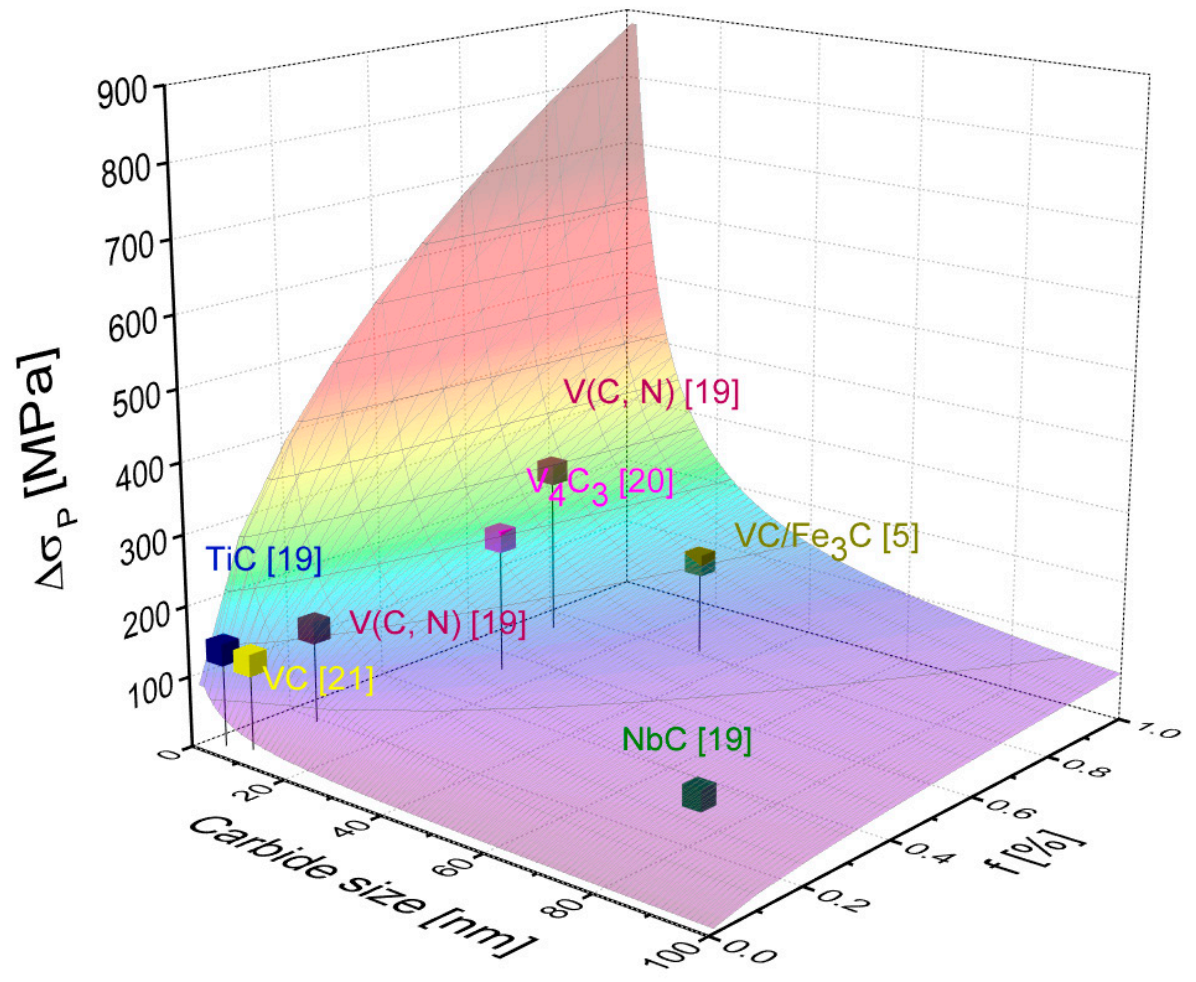

Figure 2. The calculated magnitude of precipitation strengthening using the parameters of volume fraction and size of carbides reported for TWIP steels.

Moreover, precipitates at grain boundaries exhibit the Zener-pinning effect [26] leading to interference of grain boundary motion and grain refinement during heat treatment. Thus, precipitates contribute to additional grain size strengthening. Scott et al. [19] reported an increase in YS of Fe-22Mn-0.6C steel by the addition of $0.9 \mathrm{wt} . \% \mathrm{~V}$. The VC carbides could effectively reduce the grain size from $2.5 \mu \mathrm{m}$ to $1.2 \mu \mathrm{m}$ and contribute to grain boundary strengthening, which is estimated as $125 \mathrm{MPa}$. Gwon et al. [25] reported Fe-17Mn-0.6C1.5Al TWIP steels with superior strength-ductility combination by $\mathrm{Nb}$ micro-alloying in the range of 0.01 to $0.1 \mathrm{wt} . \%$. The high YS higher than $800 \mathrm{MPa}$ is attributed to the combined effect of precipitation strengthening and partial recrystallization. Compared to complete recrystallization, partial recrystallization results in heterogeneous microstructures consisting of a mixture of recrystallized and unrecrystallized grains. The remained high density of twins and dislocations in the unrecrystallized grains could lead to an increase in YS without significant loss of ductility. This approach opened a new way to develop high-YS TWIP steel without large ductility loss.

To achieve an excellent strength-ductility combination of precipitation-hardened TWIP steels, the interaction between precipitates and defects should be considered. Yen et al. [20] investigated the interaction between the defects and $\mathrm{V}_{4} \mathrm{C}_{3}$ carbides in Fe-22Mn-0.6C-0.87V steel by transmission electron microscope (TEM) and reported that dissociated partial dislocations interacted with the $\mathrm{V}_{4} \mathrm{C}_{3}$ carbides via a bypass mechanism. The bypass mechanism usually applies to incoherent, hard precipitates, and results in strengthening of materials. When the precipitates are too strong to be cut, dislocations can effectively glide over the precipitates by leaving dislocation loops under sufficient stress. Further, the $\mathrm{V}_{4} \mathrm{C}_{3}$ carbides could hinder the propagation of deformation twins and the retarding force was dependent upon the twin thickness. The carbides could act as effective obstacles to impede the twinning propagation if the size of carbides is larger than the thickness of twins. 
Table 1. Various parameters related to precipitation strengthening of TWIP steels reported from previous works. (HR: hot-rolling, CR: cold-rolling).

\begin{tabular}{|c|c|c|c|c|c|c|c|}
\hline $\begin{array}{l}\text { Composition of } \\
\text { Materials (wt. \%) }\end{array}$ & $\begin{array}{l}\text { Precipitation } \\
\text { Condition }\end{array}$ & $\begin{array}{l}\text { Precipitate } \\
\text { Type }\end{array}$ & $\begin{array}{l}\text { Precipitate } \\
\text { Size }(\mathrm{nm})\end{array}$ & $\begin{array}{l}\text { Volume Fraction } \\
\text { of Precipitate (\%) }\end{array}$ & $\begin{array}{l}\text { Grain Size } \\
\qquad(\mu \mathrm{m})\end{array}$ & $\begin{array}{l}\Delta \mathrm{YS} \\
(\mathrm{MPa})\end{array}$ & Reference \\
\hline $\begin{array}{l}\text { Fe-21.6Mn- } \\
0.63 \mathrm{C}-0.87 \mathrm{~V}\end{array}$ & $\begin{array}{c}\mathrm{CR}+\text { Annealing } \\
\left(850^{\circ} \mathrm{C}, 60 \mathrm{~s}\right)\end{array}$ & $\mathrm{V}_{4} \mathrm{C}_{3}$ & $13 \pm 7.7$ & 0.541 & 1.2 & 200 & $\begin{array}{l}\text { Yen et al., } \\
2012 \text { [20] }\end{array}$ \\
\hline $\begin{array}{l}\text { Fe-17Mn-0.45- } \\
1.5 \mathrm{Al}-1 \mathrm{Si}-0.3 \mathrm{~V}\end{array}$ & HR & VC & 8 & 0.05 & 5.8 & 128 & $\begin{array}{l}\text { Gwon et al., } \\
2017 \text { [21] }\end{array}$ \\
\hline $\begin{array}{l}\text { Fe-16Mn-0.8C- } \\
0.5 \mathrm{Si}-0.5 \mathrm{Si}-0.5 \mathrm{~V}\end{array}$ & $\begin{array}{c}\mathrm{CR}+\text { Annealing } \\
\left(850^{\circ} \mathrm{C}, 60 \mathrm{~s}\right)\end{array}$ & $\mathrm{VC} / \mathrm{Fe}_{3} \mathrm{C}$ & 31.91 & 0.811 & 1.6 & 140 & $\begin{array}{l}\text { Kwon et al., } \\
2019 \text { [5] }\end{array}$ \\
\hline $\begin{array}{l}\text { Fe-22Mn- } \\
0.6 \mathrm{C}-0.1 \mathrm{Ti}\end{array}$ & $\begin{array}{l}\mathrm{CR}+\text { Annealing } \\
\left(740^{\circ} \mathrm{C}, 120 \mathrm{~s}\right)\end{array}$ & $\mathrm{TiC}$ & 3.8 & 0.0341 & 1.6 & 138 & \multirow{5}{*}{$\begin{array}{l}\text { Scott et al., } \\
2011[19]\end{array}$} \\
\hline $\begin{array}{l}\text { Fe-17Mn- } \\
0.9 \mathrm{C}-1.1 \mathrm{~V}\end{array}$ & $\begin{array}{l}\text { CR + Annealing } \\
\left(825^{\circ} \mathrm{C}, 120 \mathrm{~s}\right)\end{array}$ & $\mathrm{V}(\mathrm{C}, \mathrm{N})$ & 6.2 & 0.74 & 1.6 & 247 & \\
\hline $\begin{array}{l}\text { Fe-22Mn- } \\
0.6 \mathrm{C}-0.21 \mathrm{~V}\end{array}$ & $\begin{array}{c}\mathrm{CR}+\text { Annealing } \\
\left(800^{\circ} \mathrm{C}, 180 \mathrm{~s}\right)\end{array}$ & $\mathrm{V}(\mathrm{C}, \mathrm{N})$ & 7 & 0.19 & 1.9 & 137 & \\
\hline $\begin{array}{c}\text { Fe-18Mn- } \\
0.6 \mathrm{C}-0.31 \mathrm{Nb}\end{array}$ & $\begin{array}{l}\mathrm{CR}+\text { Annealing } \\
\left(750^{\circ} \mathrm{C}, 120 \mathrm{~s}\right)\end{array}$ & $\mathrm{NbC}$ & - & 0.347 & 2.3 & 58 & \\
\hline $\begin{array}{c}\text { Fe-18Mn- } \\
0.6 \mathrm{C}-0.31 \mathrm{Nb}\end{array}$ & $\begin{array}{l}\mathrm{CR}+\text { Annealing } \\
\left(800^{\circ} \mathrm{C}, 180 \mathrm{~s}\right)\end{array}$ & $\mathrm{NbC}$ & 72 & 0.322 & 2.5 & 15 & \\
\hline $\begin{array}{c}\text { Fe-18Mn- } \\
0.6 \mathrm{C}-2 \mathrm{Al}-0.05 \mathrm{Nb}\end{array}$ & HR & $\mathrm{NbC}$ & $\begin{array}{c}\text { a few tens } \\
\text { of nanome- } \\
\text { ters }\end{array}$ & - & 11 & 448 & $\begin{array}{c}\text { Kwon et al., } \\
2017 \text { [22] }\end{array}$ \\
\hline $\begin{array}{c}\text { Fe-18Mn-0.6C- } \\
1.5 \mathrm{Al}-0.1 \mathrm{Nb}\end{array}$ & HR & $\mathrm{NbC}$ & - & - & - & 278 & $\begin{array}{c}\text { Kang et al., } \\
2012 \text { [23] }\end{array}$ \\
\hline $\begin{array}{c}\text { Fe-25Mn-0.1C-3Si- } \\
\quad 3 \mathrm{Al}-0.35 \mathrm{Nb}\end{array}$ & $\begin{array}{c}\mathrm{CR}+\text { Annealing } \\
\left(1000 / 800^{\circ} \mathrm{C}, 180 \mathrm{~s}\right)\end{array}$ & $\mathrm{NbC}$ & - & - & - & 125 & $\begin{array}{l}\text { Li et al., } 2015 \\
\text { [24] }\end{array}$ \\
\hline $\begin{array}{l}\text { Fe-17Mn-0.6C- } \\
1.5 \mathrm{Al}-0.05 \mathrm{Nb}\end{array}$ & $\begin{array}{l}\mathrm{CR}+\text { Annealing } \\
\left(650^{\circ} \mathrm{C}, 100 \mathrm{~s}\right)\end{array}$ & $\mathrm{NbC}$ & - & - & $1 \sim 5$ & 140 & $\begin{array}{c}\text { Gwon et al., } \\
2018 \text { [25] }\end{array}$ \\
\hline
\end{tabular}

\section{Solid Solution Strengthening}

Solid solution strengthening of TWIP steels has been reported for various alloying elements such as C [27,28], N [29,30], $\mathrm{Al}[31,32]$, and Si [33-35]. The solid solution strengthening by alloying elements is originated from the interaction between alloying atoms and dislocations due to the size misfit between the alloying atoms and matrix atoms and modulus change, a local change of elastic constants due to the presence of the alloying atoms [10]. The magnitude of solid solution strengthening $\left(\Delta \sigma^{S S}\right)$ by alloying elements is represented by the following equation [31]:

$$
\Delta \sigma_{\mathrm{x}}^{\mathrm{SS}}=K \sqrt{c} \cdot\left(\left(\frac{1}{a} \cdot \frac{\mathrm{d} a}{\mathrm{~d} c}\right)^{2}+0.0025\left(\frac{1}{G} \cdot \frac{\mathrm{d} G}{\mathrm{~d} c}\right)^{2}\right)^{\frac{3}{4}}
$$

here $K$ is a constant, $c$ is the mole fraction of the alloying element $x, a$ is the lattice parameter of austenite, and $G$ is the shear modulus. Jung et al. [31] found that the experimentally measured solid solution strengthening contribution of $\mathrm{Al}$ is in good agreement with Equation (2) while the value of $K$ equal to 0.474 .

Figure 3 compares the estimated magnitude of solid solution strengthening from interstitial elements and substitutional elements and shows that the solid solution strengthening effect is much more pronounced for interstitial elements compared to the substitutional elements. Specifically, N shows the most pronounced solid solution strengthening effect. 
Rawers et al. [36] proposed the following equation describing the magnitude of solid solution strengthening by $\mathrm{N}, \Delta \sigma_{\mathrm{N}}^{\mathrm{SS}}$ :

$$
\Delta \sigma_{\mathrm{N}}^{\mathrm{SS}}=215+939 \% \mathrm{~N}+61 \% \mathrm{~N}^{0.5}
$$

here $\% \mathrm{~N}$ represents the weight percentage of $\mathrm{N}$ in the steel. Note that the solubility of $\mathrm{N}$ in austenitic steels is a function of the chemical composition of the steels. Especially both $\mathrm{Cr}$ and $\mathrm{Mn}$ can effectively increase the $\mathrm{N}$ solubility, thereby increasing the solid solution strengthening effect of $\mathrm{N}[29,37]$.

$C$ is the most essential interstitial element in TWIP steels and provides effective solid solution strengthening in TWIP steels. Bouaziz et al. [27] proposed an empirical equation of YS of coarse-grained $(D>20 \mu \mathrm{m})$ high Mn steels as a function of $C$ and Mn content:

$$
\mathrm{YS}(\mathrm{MPa})=228+187 \% \mathrm{C}-2 \% \mathrm{Mn}
$$

here $\% \mathrm{C}$ and \%Mn represents the weight percentage of $\mathrm{C}$ and $\mathrm{Mn}$ in the steel, respectively. Lee et al. [28] investigated the influence of $C$ concentration on YS of high-Mn steels having similar stacking fault energy (SFE) and grain size and reported a linear increase in YS with increasing carbon concentration $(241 \mathrm{MPa} / \mathrm{wt} . \% \mathrm{C})$.

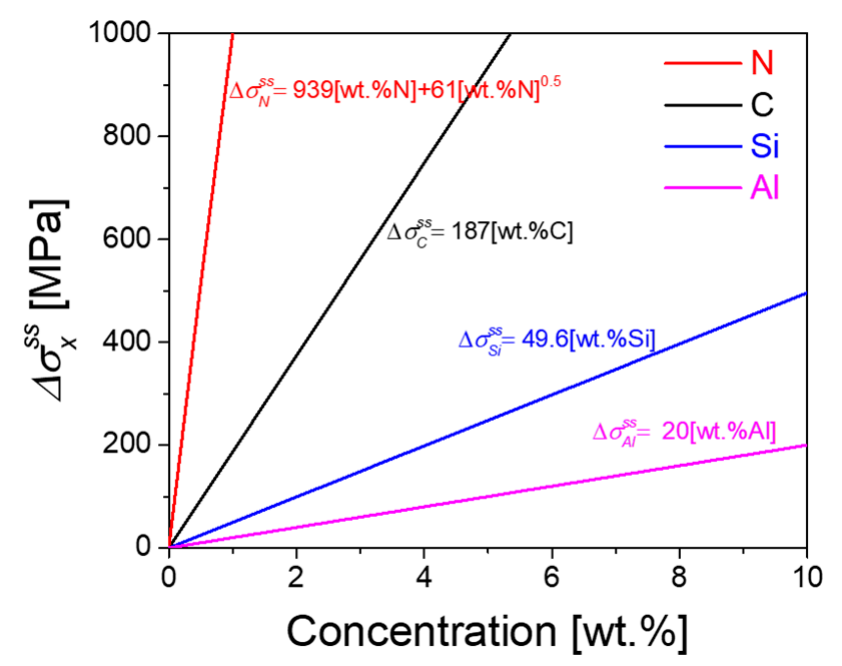

Figure 3. Estimated magnitude of solid solution strengthening from interstitial elements (N [35], $\mathrm{C}$ [27]) and substitutional elements ( $\mathrm{Si}$ [35], $\mathrm{Al}$ [31]).

\section{Effect of Thermomechanical Processing on Yield Strength}

This section will focus on various thermomechanical processing of TWIP steels to control microstructures and improve the YS of TWIP steels. Conventionally, the purpose of thermomechanical processing is to obtain: (1) Grain refinement and/or heterogeneous grain structure [6,14,38,39], (2) a dense nanoprecipitation of carbides [5,40], (3) hierarchical microstructures [17,41,42], and (4) a high density of dislocations or nano twins [43,44], which provides many penetrable and impenetrable barriers to dislocation glide.

The typical thermomechanical processing to improve YS of TWIP steels consists of cold rolling and low-temperature annealing. The low-temperature annealing can be categorized as reversion annealing (for TWIP-transformation-induced plasticity (TRIP) steels) [44], recovery annealing [45], and partial recrystallization annealing [25].

As shown in Figure 4, cold rolling generates a high density of various defects such as strain-induced martensite, grain boundaries (both high angle grain boundaries and low angle grain boundaries), deformation twins, and dislocations [44,46]. With increasing cold rolling reduction, $\varepsilon_{\text {cold }}$, shear bands are often generated from the twin-matrix (TM) rotation due to the strain localization $[47,48]$. Vercammen et al. [47] investigated the effect 
of cold-rolling reduction on deformation microstructures and mechanical properties of Fe-30Mn-3Al-3Si steel. With increasing cold-rolling reduction, deformation microstructures change from deformation twinning to inhomogeneous deformation mechanisms such as the formation of shear bands. Yanushkevich et al. [49] proposed that the YS of Fe-17Mn1.5Al-0.3C TWIP steel can be described by the following equation:

$$
\mathrm{YS}=\sigma_{0}+C\left(1-\exp \left(-\varepsilon_{\mathrm{cold}}\right)\right)\left(k_{y}-\sigma_{\rho}\right)+\sigma_{\rho}
$$

here $\sigma_{0}$ is Peierls stress, $\mathrm{C}$ is the constant which depends on the annealing time, $k_{\mathrm{y}}$ is the Hall-Petch coefficient, and $\sigma_{\rho}$ is the contribution of dislocation strengthening. However, if the density of defects such as dislocations and deformation twins saturates during the cold-rolling process, strain hardening capability is greatly reduced. Thus, to achieve the balance between strength and ductility, the reduction of the defect density by further annealing after cold-rolling is required.

As a post-process after cold-rolling, low-temperature annealing is widely used to produce heterogeneous microstructure in TWIP/TRIP steels. During the low-temperature annealing of the cold-rolled material, the cold-rolled microstructure evolves into the recovered, and the partially recrystallized microstructure with increasing annealing temperatures. The cold-rolled microstructure shows a high density of deformation twins and dislocations in deformed $\gamma$ grains (and/or mechanically induced martensite in TWIP/TRIP steels [44]). The recovered microstructure formed by the recovery annealing is characterized by annihilation and rearrangement of dislocations. However, considerable amount of deformation twins generated during the cold-rolling remain due to their thermal stability. Finally, the partially recrystallized microstructure is characterized by the coexistence of (1) recovered austenite grains with remained twins and dislocations, and (2) the recrystallized strain-free austenite grains $[25,45]$. The different microstructures depending upon the annealing conditions greatly affect mechanical properties. For example, Gwon et al. [25] reported for Fe-17Mn-0.6C-1.5Al TWIP steel that recovered material (annealed at $600{ }^{\circ} \mathrm{C}$, YS: $1263 \mathrm{MPa}$, ultimate tensile strength (UTS): $1489 \mathrm{MPa}$, total elongation (TE): 18.3\%) shows much higher YS, but limited ductility compared to the fully-recrystallized material (annealed at $800{ }^{\circ} \mathrm{C}$, YS: $524 \mathrm{MPa}$, UTS: $1096 \mathrm{MPa}$, TE: 60.1\%). The partially-recrystallized material (annealed at $650{ }^{\circ} \mathrm{C}$, YS: $781 \mathrm{MPa}$, UTS: $1218 \mathrm{MPa}$, TE: 33.6\%) showed an excellent combination of strength and ductility. One should note that both the fully recrystallized TWIP steels and the recovery annealed TWIP steels did not reveal pronounced anisotropic mechanical behavior [14].

Wesselmecking et al. [50] applied bake hardening treatment, (low-temperature aging treatment, also called paint baking treatment, applied to increase YS of steels sheets by the interaction of carbon atoms with dislocations) for Fe-19Mn-0.4C-2Cr-1 Al steel and reported that the bake hardening treatment in the temperature range from $120^{\circ} \mathrm{C}$ to $200{ }^{\circ} \mathrm{C}$ resulted in the formation of a short-range ordered $\mathrm{Mn}-\mathrm{C}$ cluster, and an increase in YS. The short- range ordering was suggested to act as obstacles for dislocation motion [51]. Essentially, the formation of $\mathrm{Mn}-\mathrm{C}$ pairs was reported to be more energetically favorable to the formation of $\mathrm{Fe}-\mathrm{C}$ pairs [52].

Warm rolling has been often utilized in the processing of TWIP steels to increase their YS. Higher temperatures used in the warm rolling compared to the cold rolling could change deformation mechanisms due to the temperature dependence of SFE [53]. Dong et al. [54] reported that the warm rolling at $400{ }^{\circ} \mathrm{C}$ increased the YS of Fe-30Mn- $4 \mathrm{Si}$ 2Al TWIP/TRIP steel from $258 \mathrm{MPa}$ for the steel before warm rolling to $785 \mathrm{MPa}$ after the warm rolling reduction of $35 \%$. Moreover, the increased dislocation density after warm rolling could enhance the effective SFE and result in a change of deformation mechanism from TRIP to TWIP/TRIP. The change of deformation mechanisms could lead to high strain hardening and high TE of $44 \%$. Brasche et al. [13] reported for Fe-18Mn-0.6C-1.2Al-0.04Si TWIP steel that the asymmetric rolling resulted in a high YS of $1047 \mathrm{MPa}$ and a high $\mathrm{TE}$ of $30 \%$. In the process of the warm rolling, the elevated temperature could suppress 
deformation twinning, and the generation of the shear strain component from asymmetric rolling could additionally contribute to the high YS.

\section{Cold-rolled microstructure}

Slip + Deformation twinning + (Mechanically induced martensite)

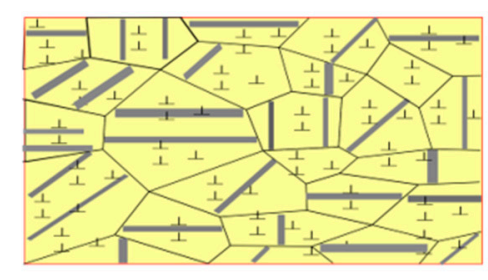

\section{Recovered microstructure}

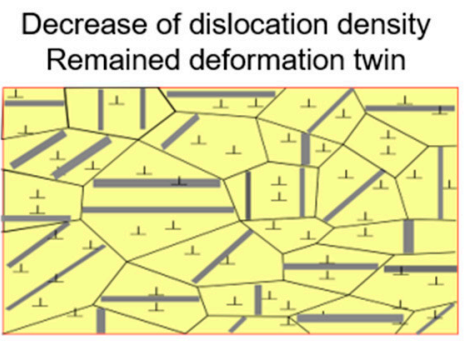

\section{Partially recrystallized microstructure}

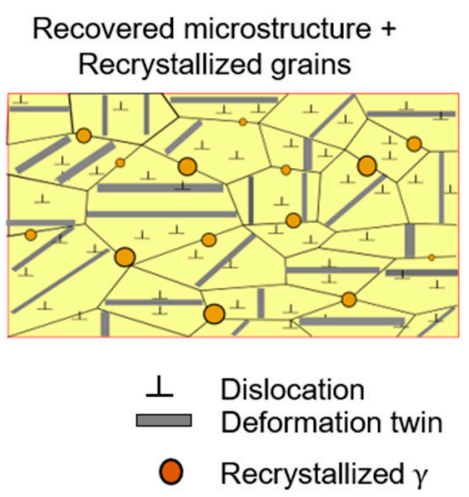

Figure 4. Thermomechanical processing consisting of cold rolling and low-temperature annealing in TWIP steels.

\section{Novel Processes to Improve the Yield Strength}

This section will focus on novel processes to improve the YS without ductility degradation in TWIP steels. Hamada et al. [16] developed a TWIP steel with a dense dislocation cell structure by using cyclic pre-straining, which showed a superior strength-ductility combination (YS of $\sim 1 \mathrm{GPa}$, TE of $\sim 50 \%$ ). The dislocation cell structures are reported to play a unique role in strengthening mechanisms, which can act as stable and penetrable barriers to glide of dislocations and result in an increase in both YS and ductility [55,56].

Multi-phase TWIP/TRIP steels have recently received increasing attention. The multiphase microstructures consisting of austenite and $\varepsilon$-martensite could be simply achieved by a combination of cold rolling and annealing of the low SFE TWIP/TRIP steels since the lowSFE alloys exhibit an intrinsic shape memory effect of reversible $\gamma$ and $\varepsilon$-martensite [57,58]. The Fe-Mn alloys which have a dual-phase microstructure consisting of $\gamma$ and $\varepsilon$-martensite generally show good ductility due to the activation of intrinsic deformation mechanisms of $\varepsilon$ martensite such as $<\mathrm{c}>$-component dislocations [59]. Li et al. [17] developed a multiphase hetero-structured Fe-18Mn-0.4C-3Cr-6Si-0.1Ni-1.6Mo-0.2Cu TWIP/TRIP steel with the microstructure consisting of fine and coarse austenitic grains with a few fine ferritic grains, which showed a YS of 1.2 GPa with a TE of 30\%. Such a high YS was originated from the combination of the hard phase and hetero-structured matrix, leading to the heterodeformation induced strengthening. TRIP and TWIP effect activated during deformation could contribute to the strain hardening of the material.

Gradient microstructures could be utilized to enhance the balance between strength and ductility of TWIP steels. Conventionally, the gradient structure provides an extra strain hardening by the geometrically necessary dislocations caused by strain gradient $[15,60,61]$. Kalsar et al. [7] reported that the gradient structure in Fe-10Mn-0.5C-3Ni TWIP steel generated by surface mechanical attrition treatment (SMAT) could increase the YS from $400 \mathrm{MPa}$ for the annealed starting material to 550MPa with maintaining an excellent ductility (TE of $\sim 52 \%$ ). Kim et al. [18] reported a gradient structured Fe-15Mn-0.6C-1.2Al TWIP steel processed by ultrasonic nanocrystalline surface modification. The material showed an excellent strength-ductility combination (YS of $\sim 800 \mathrm{MPa}$, TE of $\sim 50 \%$ ) due to the grain refinement and additional back-stress hardening.

Severe plastic deformation was also utilized to increase the YS of TWIP steels. The combination of severe plastic deformation using equal-channel angular pressing (ECAP, at $300^{\circ} \mathrm{C}$ ) and recovery annealing was introduced by Haase et al. [62]. The material showed an ultrahigh YS of $1077 \mathrm{MPa}$ and TE of 12.3\%. The ultrahigh YS was originated from the 
nanocrystalline grains $(<100 \mathrm{~nm})$ and remained deformation twins generated during the ECAP process. In addition, the decrease of dislocation density upon recovery annealing slightly recovered strain hardening and ductility. Wang et al. [63] also reported for Fe20Mn-0.5C-1.2Si-1.7Al TWIP steel that the combination of ECAP and annealing at $300{ }^{\circ} \mathrm{C}$ could result in excellent mechanical properties with YS of $1150 \mathrm{MPa}$ and TE of $19 \%$.

\section{Conclusions and Outlook}

The present work summarizes and discusses the recent progress in improving the YS of TWIP steels. Based on the discussion from the present work, Figure 5 summarizes the relationship between YS and TE of TWIP steels utilizing various strengthening mechanisms. Figure 5 shows that novel processes such as sub-boundary strengthening, multi-phase structure, and gradient structure result in exceptional properties due to the activation of multiple strengthening mechanisms. The control of thermomechanical processing (recovery annealing and warm rolling) and precipitation strengthening could also lead to an excellent combination of YS and TE, i.e., YS higher than $740 \mathrm{MPa}$ and TE larger than $30 \%$. Therefore, future works to improve the YS of TWIP steels should focus on activating multiple strengthening mechanisms by utilizing heterogeneous microstructures, preferably using economical and viable ways from the perspective of industrial applications.

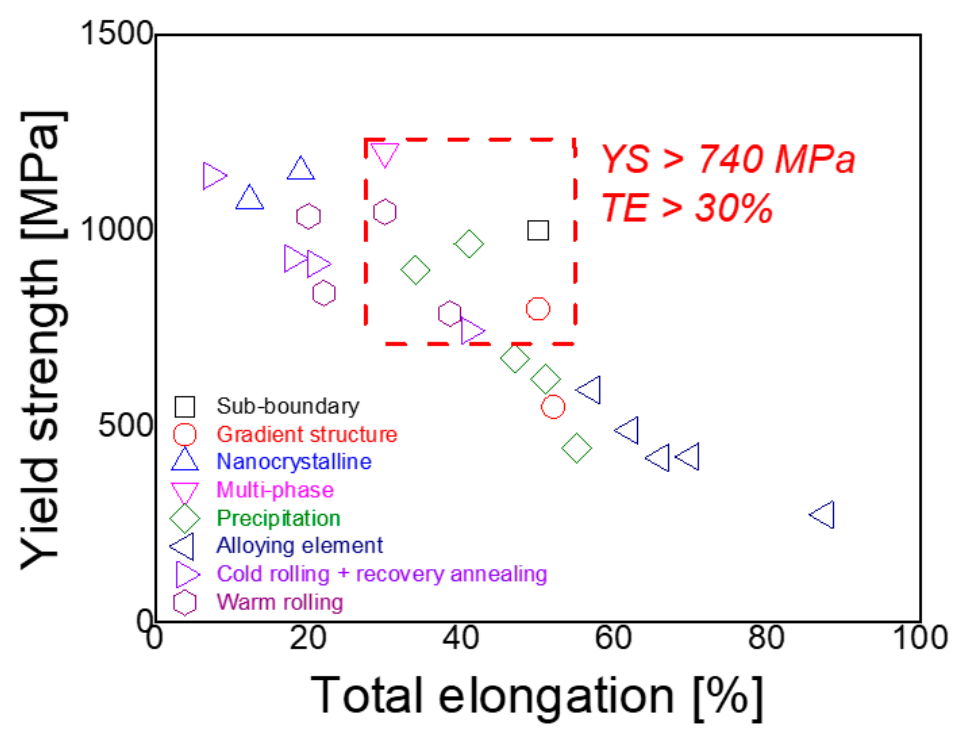

Figure 5. Summary of the relationship between YS and TE of TWIP steels utilizing various strengthening mechanisms. (WR: warm-rolling; sub-boundary [16], gradient structure [7,18], nanocrystalline [62,63], multi-phase [17], precipitation [5,21,23-25], alloying element [4,29,31,33,34], cold rolling + recovery annealing $[6,14,44,45]$, warm rolling $[13,39,42,55])$.

Author Contributions: Conceptualization, J.-K.K.; investigation, G.Y.; writing-original draft preparation, G.Y.; writing - review and editing, J.-K.K.; visualization, G.Y.; supervision, J.-K.K.; project administration, J.-K.K.; funding acquisition, J.-K.K. All authors have read and agreed to the published version of the manuscript.

Funding: This work was supported by the research fund of Hanyang University (HY-2020-2467).

Institutional Review Board Statement: Not applicable.

Informed Consent Statement: Not applicable.

Data Availability Statement: The data presented in this study are available on request from the corresponding author.

Conflicts of Interest: The authors declare no conflict of interest. 


\section{References}

1. De Cooman, B.C.; Estrin, Y.; Kim, S.K. Twinning-induced plasticity (TWIP) steels. Acta Mater. 2018, 142, 283-362. [CrossRef]

2. Bouaziz, O.; Allain, S.; Scott, C.; Cugy, P.; Barbier, D. High manganese austenitic twinning induced plasticity steels: A review of the microstructure properties relationships. Curr. Opin. Solid State Mater. Sci. 2011, 15, 141-168. [CrossRef]

3. Kim, J.-K.; De Cooman, B.C. Stacking fault energy and deformation mechanisms in Fe-xMn-0.6C-yAl TWIP steel. Mater. Sci. Eng. A 2016, 676, 216-231. [CrossRef]

4. Bambach, M.; Conrads, L.; Daamen, M.; Güvenç, O.; Hirt, G. Enhancing the crashworthiness of high-manganese steel by strain-hardening engineering, and tailored folding by local heat-treatment. Mater. Des. 2016, 110, 157-168. [CrossRef]

5. Kwon, Y.; Zargaran, A.; Ryu, J.H.; Kim, N.J. Effect of annealing conditions on the microstructure and tensile properties of $0.5 \mathrm{~V}$ containing Fe-16Mn-0.8 C-0.5 Si steel. Scr. Mater. 2019, 172, 125-129. [CrossRef]

6. Li, Y.; Lu, Y.; Li, W.; Khedr, M.; Liu, H.; Jin, X. Hierarchical microstructure design of a bimodal grained twinning-induced plasticity steel with excellent cryogenic mechanical properties. Acta Mater. 2018, 158, 79-94. [CrossRef]

7. Kalsar, R.; Suwas, S. A novel way to enhance the strength of twinning induced plasticity (TWIP) steels. Scr. Mater. 2018, 154, 207-211. [CrossRef]

8. Hansen, N. Hall-Petch relation and boundary strengthening. Scr. Mater. 2004, 51, 801-806. [CrossRef]

9. Gladman, T. Precipitation hardening in metals. Mater. Sci. Technol. 1999, 15, 30-36. [CrossRef]

10. Labusch, R. A statistical theory of solid solution hardening. Phys. Status Solidi 1970, 41, 659-669. [CrossRef]

11. Hull, D.; Bacon, D.J. Introduction to Dislocations; Butterworth-Heinemann: Oxford, UK, 2001.

12. Meyers, M.A.; Mishra, A.; Benson, D.J. Mechanical properties of nanocrystalline materials. Prog. Mater. Sci. 2006, 51, 427-556. [CrossRef]

13. Brasche, F.; Wang, J.; Timokhina, I.; Haase, C.; Lapovok, R.; Molodov, D.A. Mechanical twinning and texture evolution during asymmetric warm rolling of a high manganese steel. Mater. Sci. Eng. A 2019, 764, 138183. [CrossRef]

14. Haase, C.; Ingendahl, T.; Güvenç, O.; Bambach, M.; Bleck, W.; Molodov, D.A.; Barrales-Mora, L.A. On the applicability of recovery-annealed twinning-induced plasticity steels: Potential and limitations. Mater. Sci. Eng. A 2016, 649, 74-84. [CrossRef]

15. Wu, H.; Fan, G. An overview of tailoring strain delocalization for strength-ductility synergy. Prog. Mater. Sci. 2020, 100675. [CrossRef]

16. Hamada, A.; Järvenpää, A.; Honkanen, M.; Jaskari, M.; Porter, D.; Karjalainen, L. Effects of cyclic pre-straining on mechanical properties of an austenitic microalloyed high-Mn twinning-induced plasticity steel. Procedia Eng. 2014, 74, 47-52. [CrossRef]

17. Li, Y.; Li, W.; Li, S.; Min, N.; Jiang, L.; Zhou, Q.; Jin, X. Ensuring the strength and ductility synergy in an austenitic stainless steel: Single-or multi-phase hetero-structures design. Scr. Mater. 2020, 193, 81-85. [CrossRef]

18. Kim, J.G.; Moon, J.H.; Amanov, A.; Kim, H.S. Strength and ductility enhancement in the gradient structured twinning-induced plasticity steel by ultrasonic nanocrystalline surface modification. Mater. Sci. Eng. A 2019, 739, 105-108. [CrossRef]

19. Scott, C.; Remy, B.; Collet, J.-L.; Cael, A.; Bao, C.; Danoix, F.; Malard, B.; Curfs, C. Precipitation strengthening in high manganese austenitic TWIP steels. Int. J. Mater. Res. 2011, 102, 538-549. [CrossRef]

20. Yen, H.-W.; Huang, M.; Scott, C.; Yang, J.-R. Interactions between deformation-induced defects and carbides in a vanadiumcontaining TWIP steel. Scr. Mater. 2012, 66, 1018-1023. [CrossRef]

21. Gwon, H.; Kim, J.-K.; Shin, S.; Cho, L.; De Cooman, B.C. The effect of vanadium micro-alloying on the microstructure and the tensile behavior of TWIP steel. Mater. Sci. Eng. A 2017, 696, 416-428. [CrossRef]

22. Kwon, E.P.; Kim, D.Y.; Park, H.K. Deformation twinning in Nb-microalloyed Fe-Mn-C-Al twinning-induced plasticity steel. J. Mater. Eng. Perform. 2017, 26, 4500-4507. [CrossRef]

23. Kang, S.; Jung, J.-G.; Lee, Y.-K. Effects of niobium on mechanical twinning and tensile properties of a high Mn twinning-induced plasticity steel. Mater. Trans. 2012, 53, 2187-2190. [CrossRef]

24. Li, D.; Feng, Y.; Song, S.; Liu, Q.; Bai, Q.; Wu, G.; Lv, N.; Ren, F. Influences of Nb-microalloying on microstructure and mechanical properties of Fe-25Mn-3Si-3Al TWIP steel. Mater. Des. 2015, 84, 238-244. [CrossRef]

25. Gwon, H.; Kim, J.-K.; Jian, B.; Mohrbacher, H.; Song, T.; Kim, S.-K.; De Cooman, B.C. Partially-recrystallized, Nb-alloyed TWIP steels with a superior strength-ductility balance. Mater. Sci. Eng. A 2018, 711, 130-139. [CrossRef]

26. Nes, E.; Ryum, N.; Hunderi, O. On the Zener drag. Acta Metall. 1985, 33, 11-22. [CrossRef]

27. Bouaziz, O.; Zurob, H.; Chehab, B.; Embury, J.; Allain, S.; Huang, M. Effect of chemical composition on work hardening of Fe-Mn-C TWIP steels. Mater. Sci. Technol. 2011, 27, 707-709. [CrossRef]

28. Lee, S.-J.; Han, J.; Lee, S.; Kang, S.-H.; Lee, S.-M.; Lee, Y.-K. Design for Fe-high Mn alloy with an improved combination of strength and ductility. Sci. Rep. 2017, 7, 1-9. [CrossRef]

29. Wang, X.; Sun, X.; Song, C.; Chen, H.; Han, W.; Pan, F. Enhancement of yield strength by chromium/nitrogen alloying in high-manganese cryogenic steel. Mater. Sci. Eng. A 2017, 698, 110-116. [CrossRef]

30. Lee, S.; Kim, J.; Lee, S.-J.; De Cooman, B.C. Effect of nitrogen on the critical strain for dynamic strain aging in high-manganese twinning-induced plasticity steel. Scr. Mater. 2011, 65, 528-531. [CrossRef]

31. Jung, I.-C.; De Cooman, B.C. Temperature dependence of the flow stress of Fe-18Mn-0.6 C-xAl twinning-induced plasticity steel. Acta Mater. 2013, 61, 6724-6735. [CrossRef]

32. Jin, J.-E.; Lee, Y.-K. Effects of Al on microstructure and tensile properties of C-bearing high Mn TWIP steel. Acta Mater. 2012, 60, 1680-1688. [CrossRef] 
33. Li, D.; Feng, Y.; Song, S.; Liu, Q.; Bai, Q.; Ren, F.; Shangguan, F. Influences of silicon on the work hardening behavior and hot deformation behavior of $\mathrm{Fe}-25 \mathrm{wt} \% \mathrm{Mn}-(\mathrm{Si}, \mathrm{Al}) \mathrm{TWIP}$ steel. J. Alloy. Compd. 2015, 618, 768-775. [CrossRef]

34. Lee, S.-M.; Lee, S.-J.; Lee, S.; Nam, J.-H.; Lee, Y.-K. Tensile properties and deformation mode of Si-added Fe-18Mn-0.6 C steels. Acta Mater. 2018, 144, 738-747. [CrossRef]

35. Jeong, K.; Jin, J.-E.; Jung, Y.-S.; Kang, S.; Lee, Y.-K. The effects of Si on the mechanical twinning and strain hardening of Fe-18Mn-0.6 C twinning-induced plasticity steel. Acta Mater. 2013, 61, 3399-3410. [CrossRef]

36. Rawers, J.; Grujicic, M. Effects of metal composition and temperature on the yield strength of nitrogen strengthened stainless steels. Mater. Sci. Eng. A 1996, 207, 188-194. [CrossRef]

37. Rawers, J.; Bennett, J.; Doan, R.; Siple, J. Nitrogen solubility and nitride formation in Fe Cr Ni alloys. Acta Metall. Mater. 1992, 40, 1195-1199. [CrossRef]

38. Tian, Y.; Bai, Y.; Zhao, L.; Gao, S.; Yang, H.; Shibata, A.; Zhang, Z.; Tsuji, N. A novel ultrafine-grained Fe22Mn0. 6C TWIP steel with superior strength and ductility. Mater. Charact. 2017, 126, 74-80. [CrossRef]

39. Haupt, M.; Müller, M.; Haase, C.; Sevsek, S.; Brasche, F.; Schwedt, A.; Hirt, G. The Influence of Warm Rolling on Microstructure and Deformation Behavior of High Manganese Steels. Metals 2019, 9, 797. [CrossRef]

40. Li, S.; Chen, C.; Chen, Y.; Wang, X. The simultaneous improvement of strength and plasticity of a novel alloying steel by precipitation recovery annealing. Mater. Lett. 2020, 270, 127710. [CrossRef]

41. Xiong, T.; Zheng, S.; Zhou, Y.; Pang, J.; Jin, Q.; Ge, H.; Zheng, X.; Yang, L.; Beyerlein, I.; Ma, X. Enhancing strength and thermal stability of TWIP steels with a heterogeneous structure. Mater. Sci. Eng. A 2018, 720, 231-237. [CrossRef]

42. Yin, F.; Xia, H.; Feng, J.; Cai, M.; Zhang, X.; Wang, G.; Sawaguchi, T. Mechanical properties of an Fe-30Mn-4Si-2Al alloy after rolling at different temperatures ranging from 298 to 1073 K. Mater. Sci. Eng. A 2018, 725, 127-137. [CrossRef]

43. Zhou, P.; Liang, Z.; Liu, R.; Huang, M. Evolution of dislocations and twins in a strong and ductile nanotwinned steel. Acta Mater. 2016, 111, 96-107. [CrossRef]

44. Berrenberg, F.; Haase, C.; Barrales-Mora, L.A.; Molodov, D.A. Enhancement of the strength-ductility combination of twinninginduced/transformation-induced plasticity steels by reversion annealing. Mater. Sci. Eng. A 2017, 681, 56-64. [CrossRef]

45. Brasche, F.; Haase, C.; Barrales-Mora, L.A.; Molodov, D.A. Comparative Study of the Influence of Reversion-and RecoveryAnnealing on the Mechanical Behavior of High-Manganese Steels with Varying Stacking Fault Energy. Steel Res. Int. 2018, 89, 1700377. [CrossRef]

46. Tewary, N.; Ghosh, S.; Chakrabarti, D.; Chatterjee, S. Deformation behaviour of a low carbon high Mn TWIP/TRIP steel. Mater. Sci. Technol. 2019, 35, 1483-1496. [CrossRef]

47. Vercammen, S.; Blanpain, B.; De Cooman, B.C.; Wollants, P. Cold rolling behaviour of an austenitic Fe-30Mn-3Al-3Si TWIP-steel: The importance of deformation twinning. Acta Mater. 2004, 52, 2005-2012. [CrossRef]

48. Shen, Y.; Qiu, C.; Wang, L.; Sun, X.; Zhao, X.; Zuo, L. Effects of cold rolling on microstructure and mechanical properties of Fe-30Mn-3Si-4Al-0.093 C TWIP steel. Mater. Sci. Eng. A 2013, 561, 329-337. [CrossRef]

49. Yanushkevich, Z.; Belyakov, A.; Kaibyshev, R.; Haase, C.; Molodov, D. Effect of cold rolling on recrystallization and tensile behavior of a high-Mn steel. Mater. Charact. 2016, 112, 180-187. [CrossRef]

50. Wesselmecking, S.; Song, W.; Ma, Y.; Roesler, T.; Hofmann, H.; Bleck, W. Strain Aging Behavior of an Austenitic High-Mn Steel. Steel Res. Int. 2018, 89, 1700515. [CrossRef]

51. Kang, J.-H.; Ingendahl, T.; von Appen, J.; Dronskowski, R.; Bleck, W. Impact of short-range ordering on yield strength of high manganese austenitic steels. Mater. Sci. Eng. A 2014, 614, 122-128. [CrossRef]

52. Von Appen, J.; Dronskowski, R. Carbon-Induced Ordering in Manganese-Rich Austenite-A Density-Functional Total-Energy and Chemical-Bonding Study. Steel Res. Int. 2011, 82, 101-107. [CrossRef]

53. Latanision, R.; Ruff, A. The temperature dependence of stacking fault energy in Fe-Cr-Ni alloys. Metall. Trans. 1971, 2, 505-509. [CrossRef]

54. Dong, Y.; Sun, Z.; Xia, H.; Feng, J.; Du, J.; Fang, W.; Liu, B.; Wang, G.; Li, L.; Zhang, X. The influence of warm rolling reduction on microstructure evolution, tensile deformation mechanism and mechanical properties of an Fe-30Mn-4Si-2Al TRIP/TWIP steel. Metals 2018, 8, 742. [CrossRef]

55. Liu, L.; Ding, Q.; Zhong, Y.; Zou, J.; Wu, J.; Chiu, Y.-L.; Li, J.; Zhang, Z.; Yu, Q.; Shen, Z. Dislocation network in additive manufactured steel breaks strength-ductility trade-off. Mater. Today 2018, 21, 354-361. [CrossRef]

56. Wang, Y.M.; Voisin, T.; McKeown, J.T.; Ye, J.; Calta, N.P.; Li, Z.; Zeng, Z.; Zhang, Y.; Chen, W.; Roehling, T.T. Additively manufactured hierarchical stainless steels with high strength and ductility. Nat. Mater. 2018, 17, 63-71. [CrossRef]

57. Sato, A.; Chishima, E.; Soma, K.; Mori, T. Shape memory effect in $\gamma \rightleftharpoons \epsilon$ transformation in Fe-30Mn-1Si alloy single crystals. Acta Metall. 1982, 30, 1177-1183. [CrossRef]

58. Olson, G.; Cohen, M. A mechanism for the strain-induced nucleation of martensitic transformations. J. Less Common Met. 1972, 28, 107-118. [CrossRef]

59. Kim, J.-K.; De Cooman, B.C. Observation of dislocations with a Burgers vector containing a $\langle c\rangle$ component in martensitic hcp $\varepsilon$ Fe-17\%Mn. Scr. Mater. 2017, 128, 78-82. [CrossRef]

60. Li, X.; Lu, L.; Li, J.; Zhang, X.; Gao, H. Mechanical properties and deformation mechanisms of gradient nanostructured metals and alloys. Nat. Rev. Mater. 2020, 5, 706-723. [CrossRef] 
61. Ma, X.; Huang, C.; Moering, J.; Ruppert, M.; Höppel, H.W.; Göken, M.; Narayan, J.; Zhu, Y. Mechanical properties of copper/bronze laminates: Role of interfaces. Acta Mater. 2016, 116, 43-52. [CrossRef]

62. Haase, C.; Kremer, O.; Hu, W.; Ingendahl, T.; Lapovok, R.; Molodov, D.A. Equal-channel angular pressing and annealing of a twinning-induced plasticity steel: Microstructure, texture, and mechanical properties. Acta Mater. 2016, 107, 239-253. [CrossRef]

63. Wang, L.; Benito, J.; Calvo, J.; Cabrera, J. Equal channel angular pressing of a TWIP steel: Microstructure and mechanical response. J. Mater. Sci. 2017, 52, 6291-6309. [CrossRef] 